УДК 550.34

\title{
СЕЙСМОТЕКТОНИКА ДНЕПРОВО-ДОНЕЦКОЙ ВПАДИНЫ И ЮГО-ЗАПАДНОГО СКЛОНА ВОРОНЕЖСКОГО КРИСТАЛЛИЧЕСКОГО МАССИВА
}

\author{
Р. А. Орлов, М. А. Ефременко \\ Федеральный исследовательский центр «Единая геофизическая служба \\ Российской академии наук» (ФИЦ ЕГС РАН), г. Воронеж \\ Поступила в редакцию 1 октября 2018 г.
}

\begin{abstract}
Аннотация: дан краткий обзор геологического строения рассматриваемых структур ВосточноЕвропейской платформы (ВЕП). Предложена новая схема строения поверхности Мохоровичича, отражаюшая гериинский этап активизаиии тектонических движений в зонах рифтогенеза на древней платформе. Приведены сведения об исторических и инструментально зарегистрированных тектонических землетрясениях. Установлено, что значительная часть землетрясений тяготеет $\kappa$ северо-восточной части ДДВ и южному борту ВКМ и связана с краевыми разломами палеорифта. По результатам анализа геологических и сейсмологических данных выделены две сейсмогенные зоны, позволяюшие локализовать местоположение ожидаемых тектонических землетрясений.
\end{abstract}

Ключевые слова: Воронежский кристаллический массив (ВКМ), Днепрово-Донечкая впадина (ДДВ), землетрясения, сейсмогенные зоны.

\section{SEISMOTECTONICS OF THE DNIEPR-DONETS RIFT AND THE SOUTHWESTERN SLOPE OF THE VORONEZH CRYSTALINE MASSIF}

\begin{abstract}
Moho discontinuity of the considered tectonical elements is given. We have proposed a new version of the Moho's surface structure corresponding to Hercynian phase of tectonic movements activization in zones of rifting of the ancient craton. The data on the historical and registered instrumentally earthquakes are provided. It has been established that a significant portion of earthquakes tends to north-eastern part of the Dniepr-Donets Rift and southern slope of the Voronezh Crystaline Massif and linked to regional faults of the paleo-rift. By results of the analysis two seismogenic zones allowing to define location of the expected earthquakes are delineated.

Key words: Voronezh Crystaline Massif, Dniepr-Donets Rift, earthquakes, seismogenic zones.
\end{abstract}

\section{Введение}

Связь сложных сейсмических процессов с геологией, глубинными структурами и процессами на платформах всегда интересовала исследователей. Высокую сейсмическую активность, в отличие от альпийских областей, здесь обуславливают другие обстоятельства (причины). Исследователи сейсмичности платформенных территорий к таким обстоятельствам относят проявления новейших и современных тектонических движений (неотектоника), глубинные разломы, тектонические напряжения в недрах земли, глубинное строение коры, геофизические поля [1]. Эти причины рассмотрены нами в условиях древней Восточно-Европейской платформы, а конкретно в зоне сочленения Днепрово-Донецкой впадины (ДДВ) и Воронежского кристаллического массива (ВКМ). Для решения основной задачи - выделения мест возникновения будущих землетрясений или сейсмоген- ных зон (зон ВОЗ) в изучаемом регионе рассмотрены особенности геологического строения, в том числе глубинное строение литосферы, и проявления сейсмичности - как современной, изучаемой инструментально, так и исторической.

Выбор региона исследований объясняется как хорошей геолого-геофизической изученностью региона, так и тем, что на территории ДДВ в настоящее время ведется интенсивная добыча полезных ископаемых (уголь, нефть, газ), а на ВКМ находятся потенциально опасные объекты - крупнейший в регионе Россошанский химический комбинат, Курская и Нововоронежская атомные электрические станции.

\section{Геологическое строение ДДВ}

и осадочного чехла ВКМ

Днепрово-Донецкая впадина является крупнейшей морфоструктурой в рельефе фундамента Восточно- 
Европейской платформы. Она хорошо изучена геологическими и геофизическими методами. Только скважин глубиной 4-5 км здесь пробурено более 150. По геофизическим данным в пределах ДДВ поверхность фундамента опущена в юго-западной части на глубину 2,5 км, а в юго-восточной части она понижается до 10 и даже 25 км. В структуре Днепрово-Донецкой впадины выделяются три основных тектонических элемента - центральная (Днепровский грабен) и склоны Воронежского кристаллического массива и Украинского щита [2].

Предполагается, что Днепровский грабен был заложен как рифт в рифейское время. Мощная толща рифейских образований залегает, по данным сейсмического зондирования, на глубине 10 км и ограничена краевыми глубинными разломами-сбросами амплитудой 3-4 км. С герцинским этапом развития связана активизация тектонических движений в зонах рифтогенеза. В девоне произошло раскрытие ДнепровскоДонецкого рифта, которое сопровождалось проявлением эффузивного и интрузивного магматизма. Из современных рифтов Днепровско-Донецкого рифт по своему строению более всего напоминает Кенийский рифт, находящийся на Африканской докембрийской платформе [3, 4].

Северо-восточным бортом ДДВ является южный склон ВКМ. Поверхность пород кристаллического фундамента погружается здесь постепенно в сторону рифта (средний уклон в районе г. Белгорода 15 м/км) и перекрыта осадочными образованиями карбона. ВКМ вплоть до раннего девона представлял собой пенепленизированный щит, но именно с девона исследователи констатируют формирование Воронежской антеклизы (BА), то есть перекрытие комплексов древнего фундамента плащом отложений соответствующего возраста.

Особый интерес в наших построениях вызывает полоса шириной 35-40 км северо-западного направления в районе Курска, где фундамент перекрыт сразу юрскими породами [4]. Эта своеобразная палеоостровная постройка протяженностью более 700 км, расположенная севернее глубинного прогиба, длительное время (по крайней мере, до нижнего карбона), оставалась сушей, как и весь южный склон ВКМ. Образование поднятий вдоль щелеобразных впадин может быть связано с разуплотнением верхней части мантии и увеличения её объема [5].

\section{Рельеф поверхности Мохоровичича}

Герцинский этап тектонических движений, который начался в девоне, в пределах древней ВосточноЕвропейской платформы привел к существенной перестройке глубинных слоев земной коры, в том числе рельефа поверхности Мохоровичича $(M)$. Существует большое количество вариантов схемы (карты) поверхности Мохоровичича на эту территорию [6, 7]. Предлагаемая версия схемы рельефа поверхности Мохоровичича (рис. 1) была составлена авторами в 2011 г. и позволяет отразить основную идею - связь рельефа границы Мохоровичича с интенсивными тектоническими подвижками на платформе в герцинский этап развития [8].

Обращают на себя внимание следующие особенности. Как уже было отмечено выше, в пределах Днепрово-Донецкой впадины поверхность $M$ залегает на глубине 35,0-37,5 км и даже 32,5 км, в то время как на южном склоне ВКМ она погружается на глубину до 50 км [16]. В районе Курска наблюдается вновь повышение границы $M$ до глубин 40,0-42,5 км [6]. Это повышение протягивается в северо-западном направлении (Старый Оскол-Гомель) и совпадает с палеоостровной постройкой, расположенной севернее глубинного прогиба в карбоне (ДДВ).

Столь контрастное сочленение крупных блоков большой протяженности отвечает строению как современных рифтовых структур, так и герцинского палеорифта. Устанавливается закономерность - над впадинами происходит утонение коры, над горными сооружениями - утолщение. Граница между сегментами с «толстой» и сравнительно «тонкой» корой проходит по глубинным разломам [17].

\section{Сейсмичность изучаемой территории}

За время инструментальных наблюдений на исследуемой территории, начиная с 2000 г., было зарегистрировано 49 событий, из которых 17 сейсмических событий энергетического класса $\left(K_{P}\right) 8$ и выше $(M \geq$ $2,0)$. Подавляющее большинство гипоцентров находятся на глубинах от 1 до 5 км и только в 4 случаях глубины гипоцентров составили 8-34 км [11-15].

Расположение эпицентров землетрясений на анализируемой площади, достаточно упорядоченное они концентрируются в две структуры как в осевой части впадины, так и на ее борту - в области сочленения с ВКМ и ДДВ. Природа большинства из них, как например Новодарьинского (2004 г.), Ровеньского (2006 г.), Купянского (2009 г.) однозначно тектоническая. Одно из наиболее значительных землетрясений в районе Купянска имело класс 9,2. Его гипоцентр находился на глубине 30 км.

Установлено, что повышенной сейсмичностью характеризуются участки утолщенной земной коры с глубиной поверхности Мохоровичича более 40-50 км и значительными контрастами в рельефе подошвы коры [1]. В большинстве случаев сейсмичность свойственна также участкам коры, испытывающим напряжения субгоризонтального сжатия при стрессе, перпендикулярном альпийской складчатости [18]. Рассмотрим два последних вывода применительно к территории юго-западного склона Воронежского кристаллического массива и Днепрово-Донецкой впадины, ограничивающей массив с юга.

Изучение сейсмичности древних платформ показало, что наиболее активными в сейсмическом отношении являются рифтогенные зоны различного времени заложения и авлакогены - для которых характерно то, что наиболее сильные землетрясения (с магнитудой $M=5,0-5,5)$, в большинстве приурочены к 


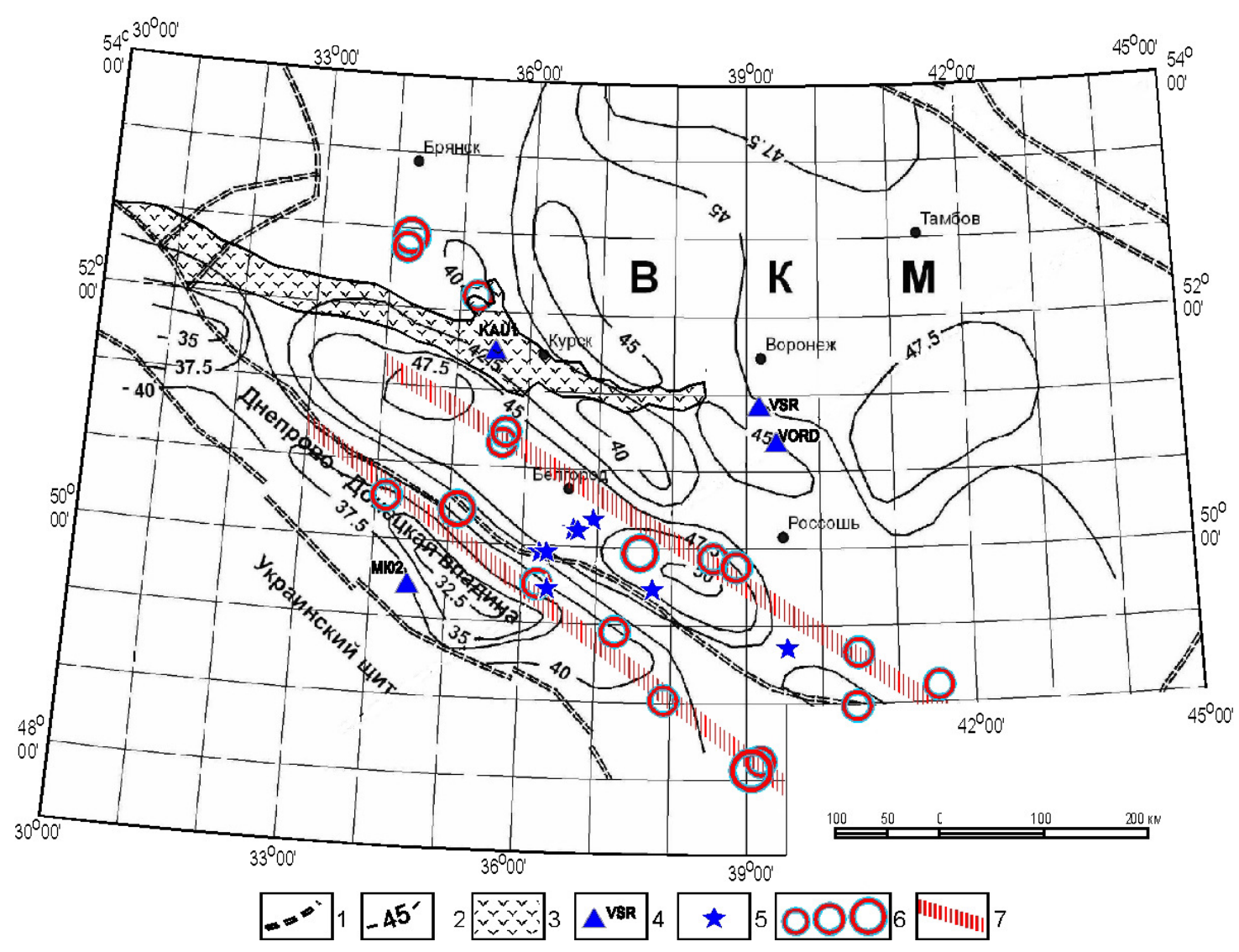

Puс. 1. Схема рельефа поверхности Мохоровичича территории ВКМ [8]: 1 - границы крупных структур ВосточноЕвропейской платформы; 2 - изолинии глубин залегания раздела Мохоровичича, 3 - палеоостровная постройка; 4 - сейсмические станции; 5 - исторические землетрясения по А. А. Никонову $[9,10] ; 6$ - землетрясения зарегистрированные сетью ВКМ (КР=8-10) [11-15]; 7 - сейсмогенные зоны.

бортовым зонам. Внутри рифтогенных зон и авлакогенов наблюдаются свои закономерности в распределении сейсмичности, которые необходимо учитывать при выделении потенциально сейсмоактивных структур более низкого ранга [19].

На рис. 1 показано распределение эпицентров наиболее значительных сейсмических событий, зарегистрированных инструментально и землетрясений, описанных в исторических документах. В плане, расстояние между сейсмогенными зонами составляет 100 км.

Из рисунка видно, что северная сейсмогенная зона приурочена к южному склону ВКМ, к области, где чехол сложен отложениями карбона, а в юговосточной части девоном. На схеме рельефа поверхности Мохоровичича зона тяготеет к максимальным мощностям земной коры (до 47,5-50 км).

Южная зона тяготеет к осевой части ДнепрновоДонецкой впадины, хотя в северо-западной части она «прижимается» к геологической (тектонической) границе ДДВ и ВКМ. На схеме поверхности Мохоровичича структура практически совпадает с градиентной зоной перехода от минимальной мощности коры к максимальной. В этой сейсмогенной зоне по крайней мере три зарегистрированных тектонических события имеют класс больше 8. Необходимо заметить, что область концентрации исторических землетрясений (1858-1928 г.г.) находится между выделенными зонами, но к точности определения эпицентров этих событий надо относиться осторожно, так как даже для наиболее сильных из них - Харьковского (1858 г.,

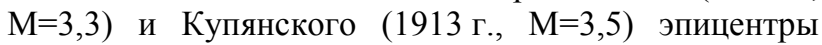
определены с точностью не хуже (!) 50 км [10].

Многие исследователи отмечают, что поднятия Украинского щита, Воронежской антеклизы и Токмовского свода, образующие эшелонированный ряд, могут отражать в большей мере влиянии Карпатского сегмента Альпийского пояса новейшего горообразования [20]. А. А. Никонов и другие исследователи считают, что на территорию ВЕП наиболее мощное воздействие оказывает с юга Аравийская плита [21]. Накопленная энергия сбрасывается в зонах сочленения крупных структур, в зонах градиентов рельефа поверхности Мохоровичича, на границах крупных плотностных и скоростных неоднородностях в верхней части земной коры (глубины до 5 км) в форме тектонических смещений, механизмы очагов которых еще предстоит изучить.

\section{Заключение}

Полученные результаты позволили сделать вывод, что землетрясения на платформенных террито- 
риях возникают закономерно в зонах, обусловленных современной тектонической активностью. Активизация разломов, возобновление смещений по ним происходит в результате процессов, происходящих в верхней мантии под древними платформами, о чем свидетельствуют инструментально зарегистрированные вертикальные движения крупных геоблоков, или за счет влияния Карпатского сегмента Альпийского пояса новейшего горообразования, о чем говорят многие исследователи.

Можно констатировать, что значительная часть инструментально зарегистрированных землетрясений и исторические землетрясения тяготеют к северовосточной части ДДВ и южному борту ВКМ и связаны с краевыми разломами палеорифта, которые отчетливо проявились в рельефе поверхности Мохоровичича. Выделены две сейсмогенные структуры, позволяющие локализовать местоположение ожидаемых тектонических землетрясений. Северная сейсмогенная зона приурочена к южному склону ВКМ, к области, где чехол сложен отложениями карбона. Южная зона тяготеет к осевой части Днепрово-Донецкой впадины и совпадает с градиентной зоной перехода от минимальной мощности коры к максимальной.

\section{ЛИТЕРАТУРА}

1. Щукин, Ю. К. Вместо предисловия. Проблемы сейсмотектоники / Ю. К. Щукин // Материалы XVII Межд. конф. Воронеж: ИПЦ «Научная книга». - 2011. - С. 3-6.

2. Андреева, Р. И. К вопросу о внутренней структуре складчатого фундамента Днепро-Донецкой впадины / Р. И. Андреева // Сов. геология. - 1961. - №6. - С. 17-28.

3. Гаврии, В. К. Геология и нефтегазоносность ДнепровоДонецкой впадины. Глубинное строение и геотектоническое развитие / В.К. Гавриш // Киев: Наук. Думка. - 1989. $208 \mathrm{c}$.

4. Трегуб, А. И. Неотектоника территории Воронежского кристаллического массива / А. И. Трегуб // Труды НИИГ Воронежского гос. ун-та. - Вып.9. - Воронеж: Изд-во ВГУ. $-2002 .-220 \mathrm{c}$.

5. Милановский, E. E. Рифтовые зоны геологического прошлого и связанные с ними образования (статья первая) / Е. Е. Милановский // Бюлл. МОИП. - Серия геол. - 1974. Х, ХІ. - Вып.5. - С. 51-71.

6. Дубянский, А. И. Структура поверхности Мохоровичича центральной части Восточно-Европейсуой платформы / А. И. Дубянский, Л. И. Надежка, А. П. Тарков // Сейсмичность и сейсмическое районирование Северной Евразии. Вып. 1.1993. - С. 162-164.

7. Юдахин, Ф. Н. Глубинное строение и современные геодинамические процессы в литосфере Восточно-Европейской платформы / Ф. Н. Юдахин, Ю. К. Щукин, В. И. Макаров // Екатеринбург: УрО РАН. - 2003. - 299 с.

Федеральный исследовательский центр «Единая геофизическая служба Российской академии наук» (ФИЦ ЕГС РАН), 2. Воронеж

Орлов Радомир Аполлонович, к.г.-м.н., стариий научный сотрудник ФИЦ ЕГС РАН

Тел.: +7 (473) 2557844

Ефременко Марина Алексеевна, к.г.-м.н., научный сотрудник ФИЦ ЕГС РАН. E-mail: 2880@mail.ru
8. Орлов, Р. А. Особенности рельефа границ Мохоровичича юго-западной части Воронежского кристаллического массива / Р. А. Орлов, О. М. Иполлитов // Проблемы сейсмотектоники. Мат-лы. XVII Межд. конф. Воронеж: ИПЦ «Научная книга». - 2011. - С. 400-404.

9. Никонов, А.А. Каталог тектонических землетрясений Центральной части Восточно-Европейской платформы / А. А. Никонов // Геодинамика и геоэкология. - Архангельск. - 1999. - С. 271-273.

10. Новый каталог сильных землетрясений на территории СССР с древнейших времен и до 1975 г. / Под ред. В. Н. Кондорской, В. Н. Шебалина. - М.: Наука. - 1977. - 536 с.

11. Пивоваров, С. П. Воронежский кристаллический массив. Каталог землетрясений за 2001 г. / С. П. Пивоваров (отв. исп.), Л. И. Надежка, И. Н. Сафронич // Землетрясения Северной Евразии в 2002 году. - Обнинск. - 2008. - (CD-ROM). 12. Пивоваров, С. П. Воронежский кристаллический массив. Каталог землетрясений за 2003 г. / С. П. Пивоваров (отв. исп.), Л. И. Надежка, И. Н. Сафронич // Землетрясения Северной Евразии в 2003 году. - Обнинск. - 2009. (CD-ROM).

13. Пивоваров, С. П. Поклассовые каталоги сейсмических событий ВКМ за 1998-2005 гг. / С. П. Пивоваров // Землетрясения Северной Евразии 2005 год. - Обнинск. - 2011. (CD-ROM).

14. Каталоги землетрясений по различным регионам России. Восточно-Европейская платформа, Урал и Западная Сибирь / Отв. сост.: И. П. Габсатарова [и др.] // Землетрясения России в 2008 году. - Обнинск: ГС РАН. - 2010. C. $142-144$.

15. Каталоги землетрясений по различным регионам России. Восточно-Европейская платформа, Урал и Западная Сибирь / И.П. Габсатарова [и др.] // Землетрясения России в 2015 году. - Обнинск: ГС РАН. - 2017. - С. 115-119.

16. Старостенко, В.И. Плотностная модель земной коры вдоль профиля DODRE / В. И. Старостенко, П. Я. Куприеко, Т. Б. Макаренко, О. В. Легостаева // Геофизический журнал. - №1. - Т. 30. - Киев. - 2008. - С. 28-41.

17. Сологуб, В. Б. Литосфера Украины / В. Б. Сологуб // Киев: Наукова Думка. - 1986. - 184 с.

18. Горшков, Г. П. Региональная сейсмотектоника территории юга России / // М.: Наука. - 1984. - 19 с.

19. Сафронов, О.Н. Строение земной коры и сейсмичность древних платформ / О. Н. Сафронов // Геодинамика. - Киев: Наукова думка. - 2008. - С. 78-88.

20. Новейшая тектоника и геодинамика: область сочленения Восточно-Европейской и Скифской плиты / В. И. Макаров и [др.] // М.: Наука. - 2006. - 206 с.

21. Никонов, А. А. Сейсмичность Восточно-Европйской платформы (ВЕП) как отражение динамического воздействия на платформу окружающих подвижных поясов / А. А. Никонов // Актуальные проблемы динамической геологии при исследовании платформенных областей: Материалы Всероссийской научной конференции. - 2016 г. C. 207-211.

Federal Research Centre "Integrated Geophysical Service of the Russian Academy of Science», Voronezh, Russia

Orlov R. A., Candidate of Geological and Mineralogical Sciences, leading scientific associate

E-mail: $\quad T e l .:$ +7 (473) 2557844

Efremenko M. A., Candidate of Geological and Mineralogical

Sciences, scientific associate

E-mail: 2880@mail.ru; Тел.: +7 (473) 2557844 